\title{
Corporate Probation Under the New Organizational Sentencing Guidelines
}

\author{
Christopher A. Wray
}

Bitter controversy greeted the United States Sentencing Commission (Commission) when it introduced the first drafts of sentencing guidelines for organizational defendants in the summer of $1988 .{ }^{1}$ Companies predicted unprecedented incursions into corporate autonomy, while public interest groups complained of inadequate deterrence. ${ }^{2}$ Three years and four drafts after its first proposal, the Commission submitted a final version of these guidelines to Congress, ${ }^{3}$ which went into effect on November 1,1991 . Among the more controversial provisions is a broad corporate probation scheme that confers significant authority on federal courts to monitor convicted companies and to force them to develop internal programs to prevent and detect misconduct. ${ }^{4}$ So dramatic are these provisions that one former prosecutor remarked:

1. U.S. Sentencing Commission, Discussion Draft of Sentencing Guidelines and Policy Statements for Organizations, 10 WHITTIER L. REV. 7 (1988); John C. Coffee, Jr. et al., Standards for Organizational Probation: A Proposal to the United States Sentencing Commission, 10 WHITTIER L. REV. 77 (1988).

2. See infra note 69 and accompanying text.

3. Amendments to the Sentencing Guidelines for United States Courts, 56 Fed. Reg. 22,762, 22,786-97 (1991) (proposed May 16, 1991) [hereinafter Guideline Amendments].

4. U.S. Sentencing Comm'N, Federal Sentencing Guidelines Manual §§ 8D1.1-.5 (1992) [hereinafter U.S.S.G.]. The sanction of "corporate probation" is hard to define briefly. In barest terms, corporate probation describes a period during which a company must satisfy certain conditions and must keep the court apprised of its compliance. Such conditions might include restitution, community service, a remedial order, adverse publicity, or forced internal reforms in corporate structure and decisionmaking. 
The next time a nominee for a federal judgeship appears for Senate confirmation, the Judiciary Committee should add to the list of legal qualifications whether the candidate can run General Motors, or Alcoa, or Nynex. If the U.S. Sentencing Commission's draft guidelines for corporate criminal sanctions become law this year, the judge might wind up managing a major corporation.

This anomaly reflects the curious and complicated nature of the corporation as a criminal defendant. ${ }^{6} \mathrm{~A}$ corporation may be vicariously criminally liable for the acts or omissions of any of its employees. ${ }^{7}$ Moreover, many corporate crimes neither require criminal intent ${ }^{8}$ nor involve morally blameworthy conduct. ${ }^{9}$ The new guidelines extend such eccentricities to the field of sentencing. Probation has historically meant conditional liberty from incarceration, permitting the rehabilitation of the defendant under a probation officer's supervi-

5. Victoria Toensing, Corporations on Probation: Sentenced to Fail, LEGAL TMMES, Feb. 12, 1990, at 21; see also L. Gordon Crovitz, Vindictive Corporate Punishments Toss Stockholders Into Stockades, WaLL ST. J., Nov. 13, 1991, at A17; Barbara Franklin, Get Ready for Guidelines: Clients Are Urged to Take Compliance Seriously, N.Y. L.J., Oct. 17, 1991, at 5.

6. Problems of definition plague this field. "Business crime" describes "a crime committed during the normal course of business operations, for economic reasons, by or on behalf of a legitimate business organization." HARRY FIRST, BUSINESS CRIME, at xxi (1990). The term "white-collar crime" has enjoyed a variety of applications and is "a distinctively social, rather than legal, concept, one suffused with vagueness and ambiguity." Stanton Wheeler, White-Collar Crime: History of an Idea, in 4 ENCYCLOPEDIA OF CRIME AND JUSTICE 1652, 1652 (Sanford H. Kadish ed., 1983). This Note focuses specifically on the punishment of "corporate crime": the punishment of organizations, not individual offenders.

The degree to which criminal behavior pervades this nation's companies remains unclear. The increasing criminalization of economic activity has meant more crimes, more prosecutions, and more convictions. See, e.g., Mark A. Cohen, Corporate Crime and Punishment: A Study of Social Harm and Sentencing Practice in the Federal Courts, 1984-87, 26 AM. CRIM. L. REV. 605, 606 (1989) (1283 corporations convicted of federal crimes from 1984 to 1987); Corporate Crime by US Companies, Bus. L. BRIEF, May 1990 (62\% of Fortune 500 "were involved" in antitrust, bribery, environmental offenses, or fraud in 1975-1984); Irwin Ross, How Lawless are Big Companies?, FoRTUNE, Dec. 1, 1980, at 56, 58 (11\% of Fortune's 800 largest companies have been convicted). See generally MARSHALL B. CLINARD \& PETER C. YEAGER, CORPORATE CRIME (1980) (broad sociological study). On the wave of corporate criminal legislation, see, e.g., 1 KATHLEEN F. BRICKEY, CORPORATE CRIMNAL LIABILITY \& 1:01 (1984); Leonard Orland, The Proliferation of Corporate Crime Legislation, 1 CORP. CRIM. LIABILITY REP. 29 (1987).

7. New York Cent. \& Hudson River R.R. v. United States, 212 U.S. 481 (1909), firmly established the criminal liability of a corporation for the acts or omissions of its agents within the scope of their employment. Such liability applies even to a company's lowest ranking agents, and the acts in question need not have benefited the company. E.g., Standard Oil Co. v. United States, 307 F.2d 120, 127-28 (5th Cir. 1962). Furthermore, the agent need not have been acting within his express authority. E.g., Continental Baking Co. v. United States, 281 F.2d 137, 149-51 (6th Cir. 1960) (apparent authority sufficient to impose criminal liability on corporation). Indeed, a corporation may be held liable for acts its agents commit against company policy. E.g., United States v. Hilton Hotels Corp., 467 F.2d 1000, 1004 (9th Cir. 1972), cert. denied, 409 U.S. 1125 (1973). Moreover, a corporation may be convicted of crimes requiring knowledge on the basis of the "collective knowledge" of its employees, even if no single employee had the requisite knowledge. E.g., United States v. Bank of New England, N.A., 821 F.2d 844 (1st Cir.), cert. denied, 484 U.S. 943 (1987). Like a corporation, a partnership may be criminally liable instead of, or in addition to, its members. See, e.g., United States v. A \& P Trucking Co., 358 U.S. 121 (1958).

8. See, e.g., United States v. FMC Corp., 572 F.2d 902, 908 (2d Cir. 1978) (strict criminal liability imposed on corporation under Migratory Bird Treaty Act).

9. Many corporate crimes are mala prohibita, not mala in se, offenses: regulatory or reporting violations often involve "morally neutral" conduct. See, e.g., 31 U.S.C. \$\$ 5313, 5322 (1988) (authorizing criminal penalties for failure to file currency transaction report). See generally Sanford H. Kadish, Some Observations on the Use of Criminal Sanctions in Enforcing Economic Regulations, 30 U. CHI. L. REV. 423 (1963). 
sion. ${ }^{10}$ Yet unlike individuals, organizations cannot be sent to jail. To apply probation to corporations, then, the Commission had to twist the meaning of the sentence to account for the peculiarity of the corporate defendant.

This Note examines both the rationale and the likely effects of the controversial probation guidelines and argues that the Commission should amend the guidelines to limit the use of corporate probation to only the most extraordinary situations. Part I identifies two schools of thought on corporate punishment and examines their implications for corporate probation. Part II traces the evolution of corporate probation to its present form, in the new guidelines. Part III examines the corporate probation guidelines in the context of their statutory mandate and in juxtaposition with existing administrative and civil sanctions. Part IV concludes with a proposal to the Commission for limiting the use of corporate probation.

\section{Two Models Influencing CoRPorate Probation}

The last thirty years have witnessed the emergence of two primary views of corporate punishment, which I will call "the Economic Model" and "the Structural Reform Model." Contrasting these two models highlights the most important issues raised by corporate probation under the new guidelines.

The Economic Model relies heavily on a "notion of the criminal as a rational [cost-benefit] calculator."11 If this portrait is ever accurate, it is so in the context of the corporate criminal defendant. Business firms are more predictably profit-motivated than individuals; corporations respond to profit incentives and disincentives in decisionmaking. ${ }^{12}$ When collectible, fines provide disincentives to break the law. ${ }^{13}$ Fines also compensate society and punish offenders, at a relatively low cost to society. ${ }^{14}$ In contrast, nonmonetary sanctions less accurately reflect the costs to society from the offense and

10. See Don M. Gottfredson, Probation and Parole: Release and Revocation, in 3 ENCYCLOPEDIA OF CRIME AND JUSTICE, supra note 6 , at 1247, 1247-54.

11. RICHARD POSNER, ECONOMIC ANALYSIS OF LAW 206 (3d ed. 1986) [hereinafter POSNER, ECONOMIC ANALYSIS]. See generally RICHARD POSNER, ANTITRUST LAW: AN ECONOMIC PERSPECTIVE 225-26 (1976) [hereinafter POSNER, ANTITRUST LAW]; Gary S. Becker, Crime and Punishment: An Economic Approach, 76 J. POL. ECON. 169 (1968); Jeffrey S. Parker, Criminal Sentencing Policy for Organizations: the Unifying Approach of Optimal Penalties, 26 AM. CRIM. L. REV. 513 (1989); Richard Posner, Optimal Sentences for White-Collar Criminals, 17 AM. CRIM. L. REV. 409 (1980) [hereinafter Posner, Optimal Sentences].

12. See Parker, supra note 11 , at $522-23$.

13. See, e.g., Posner, Optimal Sentences, supra note 11, at 414; $c$. Parker, supra note 11, at 585-86 (discussing limitation on fines where offender unable to pay, but suggesting "criminal system has traditionally been overly conservative in assessing the ability to pay").

14. See Becker, supra note 11, at 193-94, 208; cf. HERBERT L. PACKER, THE LIMITS OF THE CRIMINAL SANCTION 361-62 (1968) (suggesting reliance on criminal sanctions may be misplaced and "monetary exactions" are most appropriate sanctions); Kadish, supra note 9 (questioning wisdom of using criminal sanctions to punish what is often "morally neutral" corporate conduct); Developments in the Law-Corporate Crime: Regulating Corporate Behavior Through Criminal Sanctions, 92 HARV. L. REV. 1227, 1366 (1979) [hereinafter Developments] ("A system of fines imposed on corporations . . . should adequately deter illegal corporate activity as long as the fines are large enough to force the corporation to disgorge all benefit gained from illicit conduct."). 
consume social resources in the supervision and rehabilitation of the offender. ${ }^{15}$ Viewed from the Economic Model, corporate probation suffers from the ills of other nonmonetary sanctions: heavy administrative and supervisory costs, attenuated connection to profit incentives, less accurate measuring of monetary harm, and interference with the competitive process. ${ }^{16}$ This model rejects intervention to reform the company and questions "why the government is in a better position than the firm to provide the solution. . . . If the organization has difficulty in controlling its own agents because of bureaucracy, then there is no reason to believe that adding another layer of governmental bureaucracy has any potential for solving that problem."17 The Economic Model, then, suggests using fines in lieu of corporate probation, unless collection presents a problem.

The Structural Reform Model presents a sharp contrast to the Economic Model. ${ }^{18}$ This model views the corporate offender not as a rational, profitmaximizing calculator, but as a complex entity in which subunits, auxiliary divisions, and middle managers pursue their own "subgoals," which often clash with the aims of the corporation as a whole. ${ }^{19}$ This fragmentation of corporate goals occurs where, for instance, unit managers circumvent environmental or product-safety standards in order to increase their units' productivity, an increase that they expect will, in turn, advance their own careers. Fines, this model suggests, fail to deter many corporate offenders because the fines are either too low or are passed on to consumers, shareholders, and employees. ${ }^{20}$ Thus diluted, fines provide an inadequate incentive for internal reforms in the company's compliance policies and incentive structure. ${ }^{21}$ According to the Structural Reform Model, the government must resort to measures that will directly penetrate the bureaucratic web. ${ }^{22}$ Corporate probation is the primary

15. See Becker, supra note 11, at 194; see also POSNER, ANTTRUST LAW, supra note 11, at 225-26; Posner, Optimal Sentences, supra note 11 , at 410.

16. See Parker, supra note 11 , at 572.

17. Id. at 573 .

18. This model has emerged primarily through the works of Professors John Coffee, Brent Fisse, and Christopher Stone. See, e.g., BRENT FISSE \& PETER A. FRENCH, CORRIGIBLE CORPORATIONS AND UNRULY LAW (1985); CHRISTOPHER D. STONE, WHERE THE LAW ENDS: THE SOCIAL CONTROL OF CORPORATE BEHAVIOR (1975); John C. Coffee, Jr., "No Soul to Damn: No Body to Kick": An Unscandalized Inquiry into the Problem of Corporate Punishment, 79 MICH. L. REv. 386 (1981); Brent Fisse, Reconstructing Corporate Criminal Law: Deterrence, Retribution, Fault, and Sanctions, S6 S. CAL. L. REV. 1141 (1983); cf. Corporate Rights and Responsibilities: Hearings Before the Senate Comm. on Commerce, 94th Cong., 2d Sess. 279-301 (1976) (statement of Prof. Christopher Stone). Professor Richard Gruner appears to have joined the Coffee-Fisse-Stone triumvirate and has offered perhaps the most comprehensive discussion of structural reform through corporate probation. See Richard Gruner, To Let the Punishment Fit the Organization: Sanctioning Corporate Offenders Through Corporate Probation, 16 AM. J. CRIM. L. 1 (1988); cf. infra note 68 and accompanying text (Gruner joined Coffee and Stone to draft earliest, most aggressive corporate probation proposal to Sentencing Commission).

19. See, e.g., STONE, supra note 18, at 43-46; Coffee, supra note 18, at 393-400; Fisse, supra note 18, at 1216; Simeon M. Kriesberg, Note, Decisionmaking Models and the Control of Corporate Crime, 85 YALE L.J. 1091 (1976) (applying governmental organization models to corporate criminals).

20. See, e.g., Coffee, supra note 18, at 388-407; Fisse. supra note 18, at 1217-21.

21. See, e.g., STONE, supra note 18, at 40-41; Fisse, supra note 18, at 1217.

22. See, e.g., STONE, supra note 18 , at 121 ; Coffee, supra note 18, at 459 ; Fisse, supra note 18 , at 1245; Gruner, supra note 18 , at 72. 
criminal law vehicle of this model's adherents. They have advocated a variety of probationary conditions, including community service, ${ }^{23}$ adverse publicity, ${ }^{24}$ equity (i.e., stock) fines, ${ }^{25}$ and, most importantly, internal corporate changes. ${ }^{26}$

Neither model presents a complete guide for the use of corporate probation. The Structural Reform Model perceives two main problems with corporate fines: overspill to innocent parties and defects in corporate incentive structures. Yet the Economic Model has responses to both problems if fines are set high enough. First, a company will generally not avoid the brunt of a high fine by merely passing it on to consumers, shareholders, and employees. Overspill to these parties produces uncompetitive prices, declining share value, and the loss of productive employees: "[T]he pass-through problem can exist only if one believes that a firm, having received a criminal fine, will then proceed to shoot itself in the foot by impairing its own ability to pay the fine and generate future profits."27 Second, a company will generally reform its incentive structure in response to monetary sanctions. High fines will force firms to change the criteria for career advancement to include compliance with the law because permitting the conflicting incentives to survive would become prohibitively expensive. ${ }^{28}$ Only where upper management ignores these consequences-and yet retains control of the company-will high fines fail to produce reform. Appropriate fines, however, may sometimes exceed a company's ability to pay. Where collection is a problem, interventionist probation may both deter future misconduct and promote structural reform. In sum, high fines will address almost all corporate crimes, but courts may need the weapon of probation for two exceptional scenarios: where collectibility is in question or where, through recidivism, a company proves unresponsive to monetary penalties.

\footnotetext{
23. See, e.g., Fisse, supra note 18, at 1226-29, 1239-43; Gruner, supra note 18, at 38-41.

24. See, e.g., Coffee, supra note 18, at 424-34; Fisse, supra note 18, at 1229-31, 1239-43.

25. See, e.g., Coffee, supra note 18, at 413-24; Fisse, supra note 18, at 1233-34, 1235-37.
}

26. See, e.g., STONE, supra note 18, at 134-227 (mandatory reforms in selection and maintenance of board of directors, injection of personnel into company to monitor compliance, "disqualification" of key personnel, controls on corporate intemal information processes, and transfer of more decisions to board of directors); Coffee, supra note 18, at 448-57 (court-appointed experts to monitor company's internal reporting, compliance, and discipline mechanisms, and "judicially initiated realignment of the manager's self-interest"); Fisse, supra note 18, at 1221-26, 1237-38 ("managerial intervention"); Gruner, supra note 18, at 71-105 ("judicial intervention in internal corporate processes as a corporate probation strategy").

27. Parker, supra note 11, at 573; see also Comment, Increasing Community Control over Corporate Crime-A Problem in the Law of Sanctions, 71 YALE L.J. 280, 285 n.17 (1961) (refuting "passing on" objection to fines). Even a firm with a monopoly will not be able to pass on the costs of the fine: the firm is already charging the highest price it can, see POSNER, ECONOMIC ANALYSIS, supra note 11, at 252; if it could afford to raise prices any further, it would already have done so.

28. See, e.g., Vineeta Anand, A New Emphasis On Ethics Is Catching On In Business, INVESTOR's Bus. DAIIY, Oct. 10, 1991, at 10 (prospect of higher fines under guidelines pushing firms to develop ethics programs); Bamaby J. Feder, Helping Corporate America Hew to the Straight and Narrow, N.Y. TIMES, Nov. 3, 1991, at F5 ("Companies are fighting the high cost of misconduct with ethics programs."). 


\section{EVolution of CoRporate Probation}

\section{A. Corporate Probation Before the Sentencing Reform Act of 1984}

Until 1987, the Federal Probation Act governed corporate probation. ${ }^{29}$ This statute permitted a sentencing court to suspend the execution of a sentence and impose probation "when satisfied that the ends of justice and the best interest of the public as well as the defendant will be served thereby." 30 The court could not impose a probation term of more than five years, and could design such conditions "as the court deem[ed] best," specifically including the payment of fines and restitution "to aggrieved parties."31

Although the Federal Probation Act neither embraced nor excluded corporate defendants expressly, courts were reluctant to place corporations on probation. The Seventh Circuit broke this trend in United States v. Atlantic Richfield $\mathrm{Co}^{32}$ Atlantic Richfield pleaded nolo contendere to the charge of dumping oil into the Chicago Sanitary and Ship Canal. The district court had suspended the statutory fine and placed the company on probation for six months. In fashioning probation, the court ordered Atlantic Richfield to "set up and complete a program within 45 days to handle oil spillage into the soil and/or stream" and threatened, if the company failed to meet this condition, to appoint a "Special Probation Officer with powers of a Trustee under supervision of the court" to oversee compliance..$^{33}$ The Seventh Circuit, although agreeing with the district court that the Federal Probation Act extended to corporate defendants, found the particular conditions imposed to be well beyond the authority conferred by the Act. ${ }^{34}$

Following the Atlantic Richfield decision, district courts began to place corporations on probation more frequently. ${ }^{35}$ But like the Seventh Circuit in that case, the courts of appeals repeatedly constrained the sentencing courts' discretion under the Act. ${ }^{36}$ The debate centered on monetary conditions of

29. 18 U.S.C. $\$ \S 3651-3656$ (1982), repealed by Sentencing Reform Act of 1984, Pub. L. No. $98-473$, $\S 212(a)(1)-(2), 98$ Stat. 1987, 1987. Probation is authorized only by statute. See Ex parte United States, 242 U.S. 27 (1916).

30. 18 U.S.C. $\& 3651$ (1982).

31. $I d$.

32. 465 F.2d 58 (7th Cir. 1972).

33. Id. at 59 .

34. $1 d$. at 61 .

35. See, e.g., United States v. Danilow Pastry Co., 563 F. Supp. 1159 (S.D.N.Y. 1983) (enforcing probation condition requiring bakery companies to donate fresh baked goods to specified charitable organizations); United States v. J.C. Ehrlich Co., 372 F. Supp. 768 (D. Md. 1974) (placing company that pleaded nolo contendere on five-year probation under which it would have to pay maximum fine if convicted of similar misconduct during that period).

36. The courts of appeals generally rejected corporate probation conditions under the Federal Probation Act. See United States v. Interstate Cigar Co., 801 F.2d 555 (1st Cir. 1986) (both probation and maximum fine); United States v. John Scher Presents, Inc., 746 F.2d 959 (3d Cir. 1984) (charitable contribution); United States v. Missouri Valley Constr. Co., 741 F.2d 1542 (8th Cir. 1984) (endowment of ethics chair at state university); United States v. Wright Contracting Co., 728 F.2d 648 (4th Cir. 1984) (charitable 
probation, as several district courts attempted to make charitable contributions conditions of probation, while the courts of appeals read the Probation Act as limiting judges to either fines or restitution to identifiable victims. These cases acknowledged the Act's broad grant of discretion to the sentencing judge, but stressed the limitation "'that the conditions have a reasonable relationship to the treatment of the accused and the protection of the public."'37 Moreover, like other probationers, companies always had the option of rejecting the probation and submitting instead to the statutorily defined sentence, the fine. ${ }^{38}$ Finally, the courts of appeals guarded against the use of probation as a device to circumvent the statutory caps on monetary penalties. ${ }^{39}$ This need to curb district courts' discretion in corporate sentencing, however, illustrated the general problem with indeterminate sentencing.

\section{B. The Sentencing Reform Act of 1984}

In 1984, after years of complaints about indeterminate sentencing, Congress passed the Sentencing Reform Act (SRA). ${ }^{40}$ This statute significantly reformed the law of sentencing, including probation. Although courts continued to sentence corporations under the Federal Probation Act until November 1, $1987,{ }^{41}$ the SRA authorized the creation of the Federal Sentencing Commission and the promulgation of sentencing guidelines.

The SRA's sweeping structural changes reflect a conscious shift in congressional sentencing philosophy. Where pre-SRA law stressed rehabilitation as sentencing's primary purpose ${ }^{42}$ the SRA explicitly endorses four sentencing goals of equal priority:

(A) to reflect the seriousness of the offense, to promote respect for the law, and to provide just punishment for the offense;

contributions); United States v. Prescon Corp., 695 F.2d 1236 (10th Cir. 1982) (same); United States v. Clovis Retail Liquor Dealers Trade Ass'n, 540 F.2d 1389 (10th Cir. 1976) (contribution to county alcoholism council). But see United States v. Mitsubishi Int'l Corp., 677 F.2d 785 (9th Cir. 1982) (upholding probation requiring three companies to "lend" high-level executives' services to charity for one year without compensation and to pay contributions to same charity); United States v. Nu-Triumph, Inc., 500 F.2d 594 (9th Cir. 1974) (upholding probation requiring company not to distribute pornography).

37. Prescon, 695 F.2d at 1242 (quoting Porth v. Templar, 453 F.2d 330, 333 (10th Cir. 1971)).

38. See, e.g., Mitsubishi, 677 F.2d at 789 ("If the appellants believe that the terms of probation are more punitive than the fines, they have the option to avoid them by paying the fines." (emphasis added)); PAUL F. Cromwell et AL, PROBATION AND PAROLE IN THE CRIMINAL JUSTICE SYSTEM 37 (2d ed. 1985) (citing "[g]eneral rule" that probation cannot be imposed without defendant's consent).

39. See, e.8., Clovis Retail Liquor, 540 F.2d at 1390-91; Allantic Richfield, 465 F.2d at 61.

40. Pub. L. No. 98-473, 98 Stat. 1987 (1984) (codified as amended at 18 U.S.C. §§ 3551-3559, 35613566, 3571-3574, 3581-3586 (1988), and 28 U.S.C. $\$ \S 991-998$ (1988)). See generally MARVIN E. FRANKEL, CRMINAL SENTENCES: LAW WITHOUT ORDER (1973) (criticizing indeterminate sentencing).

41. Pub. L. No. 98-473, § 235(a)(1), 98 Stat. 1987, 2031 (1984), reprinted in 18 U.S.C. \& 3551 note (1988).

42. See, e.g., S. REP. No. 225, 98 th Cong., 2d Sess. 38 (1984), reprinted in 1984 U.S.C.C.A.N. 3182 , 3221 ("In the Federal system today, criminal sentencing is based largely on an outmoded rehabilitation model."). 
(B) to afford adequate deterrence to criminal conduct;

(C) to protect the public from further crimes of the defendant; and

(D) to provide the defendant with needed educational or vocational training, medical care, or other correctional treatment in the most effective manner. ${ }^{43}$

The SRA adds two more factors to these four traditional punishment objectives: "the need to avoid unwarranted sentence disparities among defendants with similar records who have been found guilty of similar conduct" and "the need to provide restitution to any victims of the offense." Perhaps most importantly, the SRA treats probation as a sentence in its own right, rather than as an alternative to or suspension of another sentence. ${ }^{45}$

The SRA authorizes the sentencing of an organization to either a term of probation, a fine, or both. ${ }^{46}$ In the context of corporate punishment, the SRA's legislative history reveals an emphasis on increased fines and a conservative approach to probationary conditions. Complaining that "fines generally have been an inappropriately under-used penalty in American criminal law," the Senate Judiciary Committee stressed that the SRA "makes major advances in using the mechanism of fines as an effective sanction for white collar crime and other highly profitable criminal offenses."47 Consequently, "[t] he fine levels set forth in the subsection [\$3571(b)] are considerably higher than those generally authorized by current law, and are designed to establish an effective scale for pecuniary punishment and deterrence that will reflect current economic realities."48 The SRA specifically sets corporate fines higher than fines for individuals, "both because the organization is likely to have more money available to it and because the sentence for an organization obviously cannot include a term of imprisonment." $\$ 49$ The increased fine levels, it was predicted, "would usually reach the defendant's illgotten gains while avoiding undue complexity in the sentencing hearing." 50

In drafting the SRA's probation provisions, the Committee sympathized with business groups' concerns that a probation condition prohibiting a company from engaging in a particular business "might encourage misapplication to a business that had committed a regulatory offense but that was otherwise a legitimate business." 51 Indeed, the drafters explicitly cautioned against exces-

43. 18 U.S.C. $\$ 3553(\mathrm{a})(2)$ (1988).

44. Id. $\& 3553(\mathrm{a})(6)-(7)$.

45. See S. REP. NO. 225, supra note 42, at 88, reprinted in 1984 U.S.C.C.A.N. at 3271 . This treatment of probation departed from pre-SRA law, which left defendants the option of rejecting probation and submitting to the statutorily defined sentence (usually incarceration for individuals, fines for corporations). See supra note 38 and accompanying text.

46. 18 U.S.C. \& 3551 (c) (1988).

47. S. REP. No. 225 , supra note 42 , at 103 , reprinted in 1984 U.S.C.C.A.N. at 3286.

48. Id. at 105-06, reprinted in 1984 U.S.C.C.A.N. at 3288-89 (footnote omitted).

49. Id. at 106, reprinted in 1984 U.S.C.C.A.N. at 3289.

50. Id.

51. Id. at 69, reprinted in 1984 U.S.C.C.A.N. at 3252. 
sive judicial supervision: "It is not the intent of the Committee that the courts manage organizations as a part of probation supervision ...." ${ }^{152}$ Section 3563(b) specifically requires the sentencing judge to impose only probation conditions that are "reasonably related" to the purposes of sentencing set forth in the Act, and that "involve only such deprivations of liberty or property as are reasonably necessary [for those purposes]. .53

The Sentencing Commission avoided these issues when it implemented the first sentencing guidelines in November $1987 . .^{54}$ With the exception of the guidelines specifically addressing antitrust violations, ${ }^{55}$ the 1987 guidelines do not apply to organizations. Moreover, the 1987 antitrust guidelines provide only for corporate fines and not corporate probation.

Into this limbo stepped District Judge Robert Doumar. In United States $v$. Allegheny Bottling $\mathrm{Co}_{0},{ }^{56}$ he faced the price-fixing conviction of the Allegheny Pepsi-Cola Bottling Company. He sentenced the corporation to a $\$ 1$ million fine and three years imprisonment. "The key to corporate imprisonment," wrote Judge Doumar, "is this: imprisonment simply means restraint." ${ }^{\text {"57 }}$ He depicted a scenario in which the U.S. Marshal would seize the company's assets, close and guard its physical plant, and limit the comings and goings of employees. ${ }^{58}$ "Who am I to say that imprisonment is impossible when the keeper indicates that it can physically be done?" he asked..$^{59} \mathrm{He}$ then suspended all but $\$ 50,000$ of the fine, suspended execution of the sentence of imprisonment, and placed the company on probation for three years. ${ }^{60}$ Judge Doumar required, "[a]s special conditions of the probation," that Allegheny provide four executives, "of comparable salary and stature" to four former executives involved in the price fixing, to perform forty hours per week of community service for oneand two-year periods. ${ }^{61}$ In addition, he ordered Allegheny not to "dispose of any of its franchises, capital assets or plants or facilities" in the areas in which the price-fixing conspiracy had occurred without his specific permission. ${ }^{62} \mathrm{He}$ characterized his decision as consistent with the purposes of sentencing-incapacitation, deterrence, rehabilitation, and just punishment--that the Sentencing

52. Id. at 99 , reprinted in 1984 U.S.C.C.A.N. at 3282 (seeking to "allay the fears of such disparate groups as the ACLU and the Business Roundtable that probation conditions might be too restrictive in a particular case or might involve more supervision than is justified").

53. 18 U.S.C. $\$ 3563$ (b) (1988).

54. U.S.S.G., supra note 4. In Mistretta v. United States, 488 U.S. 361, 412 (1989), the Supreme Court upheld the constitutionality of the Commission and the Sentencing Guidelines.

55. U.S.S.G., supra note $4, \S 2 \mathrm{R} 1.1$.

56. 695 F. Supp. 856 (E.D. Va. 1988), aff' $d$ in part \& rev' $d$ in part sub nom. United States v. Harford, 1988-2 Trade Cas. (CCH) I 68,386 (4th Cir.) (per curiam), cert. denied, 493 U.S. 817 (1989).

57. Id. at $859-60$.

58. Id. at 861 .

59. Id.

60 . Id. at 858.

61. Id. at 858-59.

62. Id. at 859 . 
Commission set forth in its first guidelines manual. ${ }^{63}$

In a per curiam decision, the Fourth Circuit disagreed. Allegheny had fully and promptly paid the maximum fine of $\$ 1$ million, and the court labeled the rest of the sentence "a nullity." Judge Doumar had overstepped his authority, for under the Sherman Act, "there are no additional or alternate sanctions which would even suggest imprisonment or probation of a corporation." 65 Ordering the district court to remove all of Allegheny's sentence except the fine, the court of appeals remanded the case. Judge Doumar's expansive view of permissible corporate punishment, and the Fourth Circuit's cursory rejection of that view, illustrates the need for clear corporate sentencing principles.

\section{The New Organizational Sentencing Guidelines}

Having promulgated sentencing guidelines for individual defendants, the Commission began serious discussion of organizational sentencing in July 1988 by circulating two proposals. One proposal emphasized monetary sanctions, and fines in particular. ${ }^{66}$ This proposal treated corporate probation primarily as a means of securing payment of fines or restitution. ${ }^{67}$ The other proposal urged the Commission to "treat ... probation as a frequently desirable means to secure continuing judicial control over organizational offenders and thereby promote organizational reform following a serious offense. ${ }^{.68}$ Controversy erupted: businesses and corporate law firms pressed for lighter fines and less intrusive probation, while environmental and other public interest groups lobbied for stiffer penalties and greater oversight of corporate behavior. ${ }^{69}$ On April 26, 1991, less than a week before the May 1 statutory deadline and almost three years after circulating its first proposed guidelines, the Commission sent a final draft to Congress. ${ }^{70}$ Because Congress did not exercise its authority to intervene, these guidelines became effective on November $1,1991 .^{71}$

63. Id. at 863 (citing U.S.S.G., supra note $4, \S 1.1$ ). Curiously, after stating that the corporate sentence was "specifically tailored" to these four goals of sentencing, Judge Doumar only discussed incapacitation and deterrence; he never elaborated on his claim that the punishment comported with rehabilitation and just punishment. See id.

64. United States v. Harford, 1988-2 Trade Cas. (CCH) of 68,386, at 60,133 (4th Cir. 1989).

65. Id. (citing Melrose Distillers, Inc. v. United States, 359 U.S. 271 (1959) (corporation cannot be imprisoned)).

66. U.S. Sentencing Commission, supra note 1 (draft developed by Commissioner Michael Block and Deputy Chief Counsel Jeffrey Parker).

67. Id. $\$ 8 \mathrm{D} 2.1$, at 64 .

68. Richard Gruner, Special Issue on Organizational Sanctions: Introduction, 10 WHITTIER L. REV. 1,3 (1988) (discussing proposal coauthored with Coffee and Stone, see Coffee et al., supra note 1).

69. See Stanley S. Arkin, Corporate Sentencing Guidelines-Again, N.Y. L.J., Oct. 11, 1990, at 3; Fred Strasser et al., The Corporate Sentencing Fight is Postponed, NAT'L L.J., Apr. 23, 1990, at 5; Fred Strasser, Corporate Sentences Draw Fire; Big Business Attacks Proposals, NAT'L L.J., Mar. 12, 1990, at 3.

70. Guideline Amendments, supra note 3; Organizational Sentencing Guidelines Adopted by Federal Sentencing Commission, 59 U.S.L.W. 2661 (May 7, 1991) [hereinafter Guidelines Adopted]. Amendments to the Sentencing Guidelines must be sent to Congress before May 1 of each year to take effect in that year. 28 U.S.C. \& 994(p) (1988).

71. See Congress Has No Plans To Review Corporate Crime, CoRP. FIN. WK., Oct. 7, 1991, at 9. 
The new guidelines significantly increase the size of the fines courts may impose against corporate offenders. At one extreme, if the sentencing court determines that the defendant "operated primarily for a criminal purpose or primarily by criminal means," then the guidelines require a fine "sufficient to divest the organization of all its net assets." ${ }^{\text {"72 }}$ This sort of corporate death penalty will apply only where the defendant has essentially no legitimate business operations. ${ }^{73}$ Yet the rationale behind the divestment provision - that the size of the fine should track the "seriousness" of the offense - underlies the remaining guidelines for fines as well. The "base fine" imposed reflects the seriousness of the offense by requiring the organization to pay the greater of the fine set by the guidelines' offense-level table, the defendant's monetary gain, or the monetary loss caused by the offense if caused "intentionally, knowingly, or recklessly." dollar figure by taking into account various "culpability" factors. ${ }^{75}$ The maximum fine within these guidelines could reach as high as $\$ 290$ million, easily outdistancing pre-guidelines fine levels. ${ }^{76}$

In addition, the guidelines specifically provide for restitution, ${ }^{77}$ remedial orders, ${ }^{78}$ community service, ${ }^{79}$ and orders of notice to victims. ${ }^{80}$ These sanctions are all designed to promote a general principle of corporate punishment - 'that the organization take all appropriate steps to provide compensation to victims and otherwise remedy the harm caused or threatened by the offense." Likewise, all four sanctions may be imposed as conditions of probation.

The guidelines include a broad scheme of mandatory corporate probation. They require the use of probation if necessary to ensure the defendant compa-

72. U.S.S.G., supra note $4, \S 8 \mathrm{Cl}$.1.

73. Id. $\$ 8 \mathrm{Cl} .1 \mathrm{cmt}$. (listing organizations set up to commit fraud, drug rings, and "hazardous waste disposal business that had no legitimate means of disposing of hazardous waste" as type of defendants prompting divestment).

74. Id. $88 \mathrm{C} 2.4$.

75. These factors include: the company's degree of "involvement in or tolerance of criminal activity"; any prior history of similar misconduct; violation of a judicial order, injunction, or condition of probation; obstruction of justice; the use of an "effective program to prevent and detect violations of law"; and "selfreporting, cooperation, and acceptance of responsibility." Id. $\$ 8 \mathrm{C} 2.5$.

76. One noteworthy study of corporate punishment in 1984-87 found only two fines in excess of $\$ 500,000$; the highest fine imposed was $\$ 3.6$ million. See Cohen, supra note 6 , at 611 ; $c f$. Stanley S. Arkin, Corporate Sentencing Guidelines, N.Y. L.J., June 13, 1991, at 3 (noting "average penalty for convicted corporations is likely to rise dramatically" under new guidelines). Moreover, a company may have to pay restitution to victims of the offense in addition to the fine. 18 U.S.C. $\$ \S 3556,3663$ (a) (1988).

These new fines do not apply to environmental, wildlife, food and drug, or civil rights offenses. See U.S.S.G., supra note $4,8 \S 8 \mathrm{A1} 1.1 \mathrm{cmt}$., $8 \mathrm{C} 2.1$ \& cmt. Although the remainder of the new guidelines-the provisions pertaining to probation, restitution, community service, and notice to victims--do apply to these offenses, the Commission has not set fine levels for organizational violations of these laws. Instead, sentencing courts have discretion within the general principles of the Sentencing Reform Act, 18 U.S.C. 883553,3572 (1988). See U.S.S.G., supra note 4, \$ 8C2.10.

77. U.S.S.G., supra note $4, \S 8 \mathrm{~B} 1.1$.

78. Id. $\$ 8 \mathrm{~B} 1.2$.

79. Id. $\$ 8 \mathrm{~B} 1.3$.

80. Id. $\$ 8 \mathrm{~B} 1.4$.

81. Id. ch. 8 , pt. $\mathrm{B}$, intro. cmt. 
ny's compliance with some other sanction, such as a fine, restitution, a remedial order, or community service. ${ }^{82}$ Probation is also required if in the five years before sentencing, the organization, or a "high-level" individual within it, engaged in "similar misconduct."

Perhaps most significantly, the guidelines mandate the use of probation if the company "does not have an effective program to prevent and detect violations of law." "S4 Such a program must satisfy a rigorous checklist requiring "at a minimum": (1) compliance standards and procedures; (2) specific highranking executives assigned to oversee compliance; (3) no delegation to employees "whom the organization knew, or should have known through the exercise of due diligence, had a propensity to engage in illegal activities"; (4) compliance training programs or publications for all employees; (5) channels for whistleblowers to report misconduct "without fear of retribution"; (6) the use of disciplinary mechanisms against individuals responsible for offenses or who failed to detect offenses; and (7) a response of "all reasonable steps" to any offenses detected. ${ }^{85}$ The guidelines add that " $[t]$ he larger the organization, the more formal the program typically should be," that certain sorts of businesses may include a greater risk of offenses requiring increased safeguards, and that recurrence of similar misconduct should weigh against a finding of an "effective" compliance program. ${ }^{86}$ Finally, the guidelines include two catchall provisions that require probation if "necessary to ensure that changes are made within the organization to reduce the likelihood of future criminal conduct, ${ }^{, 87}$ or "to accomplish one or more of the purposes of sentencing set forth in [the SRA]."88

The guidelines include both mandatory and discretionary conditions of probation. In keeping with the SRA, the sentencing court must require every probationer not to commit another federal, state, or local crime while on probation. ${ }^{89}$ If the underlying offense was a felony, the court must order the company to pay a fine, pay restitution, or perform community service in addition to, and as a condition of, probation. ${ }^{90}$

82. Id. $\S 8 \mathrm{D} 1.1(\mathrm{a})(1)$-(2). Indeed, probation is required if the organization has not paid all monetary penalties "in full at the time of sentencing, and restrictions are necessary to safeguard the organization's ability to make payments." $I d$. $\S 8 \mathrm{D} 1.1(\mathrm{a})(2)$. This provision alone is likely to lead to frequent use of probation. See Toensing, supra note 5, at 22 ("Non-payment at that stage [the time of sentencing] will, of course, be commonplace."). In addition, probation is mandatory in all instances where the court has imposed no fine. 18 U.S.C. \& 3551(c) (1988); U.S.S.G., supra note 4, \& 8D1.1(a)(7).

83. U.S.S.G., supra note $4, \S 8 \mathrm{D} 1.1(\mathrm{a})(4)-(5)$.

84. Id. $\S 8 \mathrm{D} 1.1(\mathrm{a})(3)$.

85. Id. $\$ 8 \mathrm{~A} 1.2 \mathrm{cmt} .3(\mathrm{k})$.

86. Id. $\S 8 \mathrm{~A} 1.2 \mathrm{cmt} 3(\mathrm{k})(7)(\mathrm{i})$-(iii).

87. Id. \& 8D1.1(a)(6).

88. Id. § 8D1.1(a)(8) (citing 18 U.S.C. $\S 3553(a)(2)(1985)$ ). The SRA's sentencing purposes are quoted in Part II.B.1, supra. See supra text accompanying notes 43-44; cf. infra Part III.A (discussing ways in which corporate probation under guidelines undermines SRA's purposes).

89. U.S.S.G., supra note $4, \S 8 \mathrm{D} 1.3(\mathrm{a})$.

90. Id. \& 8D1.3(b). 
The guidelines also permit the court to impose a wide variety of other conditions. First, the court may order the company to publicize, at its own expense, the nature of the offense, the conviction, the sentence imposed, and the steps it will take to prevent recurrence. ${ }^{91}$ Second, the court may demand that the company make "periodic submissions" to the court or a designated probation officer detailing the company's financial condition and the results of its business operations, including an accounting for all revenue. ${ }^{92}$ Third, the court may force the company to submit to "regular or unannounced examinations of its books and records" and the "interrogation" of its officials. ${ }^{93}$ The guidelines delegate this monitoring responsibility to probation officers or courtappointed experts, paid for by the corporate probationer itself. Fourth, the court may require immediate notification concerning any adverse change in the company's financial condition or prospects, and the commencement of any proceeding or investigation against the organization. ${ }^{94}$ Finally, the court may require the organization to develop and submit a compliance program and a schedule for its implementation..$^{95}$ If the court approves the program, the company must alert its employees and shareholders to the criminal behavior and the implementation of the compliance program, and must make "periodic reports" to the court or probation officer concerning the program's progress. ${ }^{96}$ The guidelines supplement these conditions by granting discretion to impose others, although cautioning that these other conditions must be "reasonably related to the nature and circumstances of the offense or the history and characteristics of the organization" and "involve only such deprivations of liberty or property as are necessary to effect the purposes of sentencing." 97

Probation under the guidelines may last up to five years and must last at least one year for felonies. ${ }^{98}$ During that time, the court may punish probation violations by extending the term, increasing the restrictiveness of the conditions, revoking probation and resentencing the organization, or "in the event of repeated, serious violations," appointing a trustee to oversee compliance. ${ }^{99}$

\section{Assessing PROBation UNDER the NeW GUIDELINES}

The new guidelines' corporate probation provisions are comprehensive and ambitious, yet flawed. This part examines the provisions against the backdrop of their statutory mandate and in juxtaposition with existing administrative and

\footnotetext{
91. Id. $88 \mathrm{D} 1.4(\mathrm{a})$.

92. Id. \& 8D1.4(b)(1).

93. Id. \& 8D1.4(b)(2).

94. Id. \& $8 \mathrm{D} 1.4(\mathrm{~b})(3)$

95. Id. \& 8D1.4(c)(1).

96. 1 d. $\$ 8 \mathrm{D} 1.4(\mathrm{c})(2)-(3)$.

97. Id. \& 8D1.3(c).

98. $I d . \& 8 \mathrm{D} 1.2$.

99. Id. $\$ 8 \mathrm{D} 1.5 \& \mathrm{cmt}$.
} 
civil enforcement mechanisms.

\section{A. Promotion of the Sentencing Reform Act's Stated Purposes}

An important measure of the legitimacy of the new guidelines' probation provisions lies in the degree to which they promote the SRA's sentencing purposes. As previously noted, these purposes are codified in 18 U.S.C. $\S 3553(\mathrm{a})^{100}$ and must be considered by a judge when designing probationary conditions. ${ }^{101}$ Essentially, the SRA requires corporate probation to further six objectives: (1) "just punishment"; ${ }^{102}$ (2) deterrence; ${ }^{103}$ (3) incapacitation; ${ }^{104}$ (4) rehabilitation; $;{ }^{105}(5)$ determinacy; ${ }^{106}$ and (6) restitution to victims. ${ }^{107}$ Sentencing under the new guidelines does not require a choice between these philosophical objectives, for the SRA "has deliberately not shown a preference for one purpose of sentencing over another."108

\section{1. "Just Punishment"}

Under this principle, a company's sentence should reflect its "just deserts."109 This "just deserts" notion draws from the traditional concept of retribution ${ }^{110}$ but stresses proportionality: the sentence imposed should reflect the seriousness of the offense. ${ }^{111}$ The seriousness of an offense, in turn, stems from two elements: the amount of harm caused and the offender's degree of culpability. ${ }^{112}$

In most situations under the guidelines, corporate fines and restitution will closely reflect a company's "just deserts." When a court imposes a fine on an

100. See supra notes $43-44$ and accompanying text (quoting SRA).

101. 18 U.S.C. \$ 3563(b) (1988); cf. S. REP. No. 225, supra note 42, at 74-75, reprinted in 1984 U.S.C.C.A.N. at 3257-58 ("One of the most glaring defects in current [pre-SRA] sentencing law is the absence of general legislative guidance conceming the factors to be considered in imposing sentence.").

102. See 18 U.S.C. \& 3553(a)(2)(A) (1988).

103. See id. \$ 3553(a)(2)(B).

104. See id. $\$ 3553(\mathrm{a})(2)(\mathrm{C})$.

105. See id. $\$ 3553(\mathrm{a})(2)(\mathrm{D})$.

106. See id. \$3553(a)(6).

107. See id. \& 3553(a)(7).

108. S. REP. No. 225 , supra note 42 , at 77 , reprinted in 1984 U.S.C.C.A.N. at 3260.

109. See id. at 75, reprinted in 1984 U.S.C.C.A.N. 3258 (describing $\$ 3553(a)(2)(A)$ as "essentially the "just deserts' concept").

110. 3 ABA STANDARDS FOR CRIMINAL JUSTICE 18-8 (2d ed. 1980) ("[R]etribution should provide not a justification but a limit .... a ceiling on punishment that may not be exceeded on utilitarian grounds."); $c f$. Exodus 21:24 ("eye for eye, tooth for tooth").

111. See, e.g., ERNEST VAN DEN HAAG, PUNISHING CRIMINALS 11 (1975) ("Justice . . weighs the gravity of the crime on her scales to reestablish the equilibrium disturbed by the offense through an equally weighty punishment."); ANDREW vON HIRSCH, DONG JUSTICE: THE CHOICE OF PUNISHMENTS 66 (1976) ("Severity of punishment should be commensurate with the seriousness of the wrong.") (emphasis omitted); cf. Richard Posner, Retribution and Related Concepts of Punishment, 9 J. LEGAL STUD. 71 (1980) (retribution is consistent with economic theory of punishment).

112. E.g., VON HIRSCH, supra note 111 , at $79-81$. 
organization, it must calculate the level of that fine based on the harm caused by the offense but adjusted substantially to reflect the corporation's culpability. ${ }^{113}$ For example, a large defense contractor convicted of procurement fraud would pay, in addition to restitution, a fine based on the amount of the harm caused, increased by factors such as significant planning, involvement of senior management, and any efforts to conceal detection.

In contrast, three principal types of probation are possible under the guidelines, but only the first promotes "just deserts." The first variety makes payment of a fine or restitution a condition of probation; it simply increases the consequences of noncompliance with these monetary sanctions. ${ }^{114}$ Here the monetary penalty is the proportionate sanction, and probation merely plays a supporting role. Probation of this sort is entirely consistent with the SRA. ${ }^{115}$ The second variety makes adverse publicity a condition of probation. ${ }^{116}$ Here, the embarrassment and stigma of the publicity are imposed as the company's "just deserts" for its criminal behavior. ${ }^{117}$ Such probationary conditions are retributive but less likely to be proportionate than are monetary conditions because the "size" or gravity of the adverse publicity order is less certain and less quantifiable. ${ }^{118}$ The retributive force of such probation depends on "the fickle jury of public opinion."119 The third variety uses the probation itself as the primary punishment, imposing substantial constraints on corporate autonomy. Provisions requiring the company to develop a compliance program under the court's and probation officer's close supervision are more forward looking than retributive. In most instances, such intervention mirrors the amount of harm and the degree of culpability less precisely than fines and restitution do. The rare, but important, exception is the recidivist company. That context could justify significant monitoring through probation because the company has been so delinquent as to "deserve" the most drastic sanctions available. Except in such extraordinary situations, fines provide "just punishment" more precisely than probation does.

113. See U.S.S.G., supra note 4, $\S \S 8 \mathrm{C} 2.4-8 \mathrm{C} 2.5$; supra notes 7476 and accompanying text. Fines under the guidelines pay close attention to the size of the organization in assessing culpability; the probation guidelines, in contrast, virtually ignore the size of the organization. Compare U.S.S.G., supra note 4, $\$ 8 \mathrm{C} 2.5$ (b) (culpability adjustment varies with five different size levels of organizations) with id. $\$ 8 D 1.1(3)$ (organization of fewer than 50 employees not required to have compliance program).

114. See U.S.S.G., supra note 4, § 8D1.1(a)(1)-(2); supra notes 82,90 and accompanying text.

115. See 18 U.S.C. $\$ 3563(b)(2)-(3)$ (1988).

116. See U.S.S.G., supra note 4, § 8D1.4(a); supra text accompanying note 91 .

117. The adverse publicity sanction is advocated at length in BRENT FISSE \& JOHN BRATHHWATTE, THE IMPACT OF PUBLICITY ON CORPORATE OFFENDERS (1983); Brent Fisse, The Use of Publicity as a Criminal Sanction Against Business Corporations, 8 MELB. U. L. REV. 107 (1971).

118. See, e.g., Coffee, supra note 18, at 427 ("Adverse publicity is something of a loose cannon; its exact impact cannot be reliably estimated nor is it controllable so that only the guilty are affected."). Even Coffee, no enthusiast of cash fines, concedes that "it seems easier to rely on even cash fines in preference to the wholly unpredictable impact of a legal stigma." Id. at 428. Moreover, "the civil law can also achieve the[l goals [of publicity] . . . with less effort and greater precision" through corrective advertising orders and the like. Id.

119. Fisse, supra note 18 , at 1231. 


\section{Deterrence}

Deterrence features prominently in both the Economic and the Structural Reform Models ${ }^{120}$ and represents the most significant objective in corporate punishment. ${ }^{121}$ Essentially, deterrence rests on consequentialist grounds: a punishment should increase the expected costs of the crime until they outweigh its expected benefits. ${ }^{122}$ To the extent that businesses are more likely than other offenders to make decisions along cost-benefit lines, deterrence is particularly well suited to corporate crime. ${ }^{123}$

Generally, corporate probation under the new guidelines will deter, but less efficiently and less predictably than will fines and restitution. The prospect of unannounced examinations of their books and interrogations of their employees $^{124}$ may frighten companies into trying harder to obey the law. Companies may react similarly to the risk of having a court and its appointed "experts" monitor and review their internal compliance programs. ${ }^{125}$ The threat of adverse publicity provided at company expense may be similarly daunting. ${ }^{126}$

Yet the deterrent effect of each of these conditions of probation lies only in their financial implications. Companies will fear each sanction because of its expense and, especially, because of the unpredictability of that expense. "No matter what form the penalty takes, its ultimate impact on the organization is likely to be evaluated in monetary or economic terms-by investors, competitors, and others-because financial results are the only purpose of the organization and the only measure of its performance in the marketplace."127 If companies overestimate the costs of probation, they will be overdeterred: they will spend more money on compliance mechanisms than needed to detect and

120. Compare POSNER, ECONOMIC ANALYSIS, supra note 11, at 205-11 (arguing that monetary sanctions can deter offender by making expected punishment costs prohibitively high) with Coffee, supra note 18 , at 388-407 (advocating intervention because cash fines are inadequate to deter corporate crime).

121. See S. REP. NO. 225, supra note 42, at 76 , reprinted in 1984 U.S.C.C.A.N. 3259 (describing deterrence as "particularly important in the area of white collar crime").

122. See, e.g., POSNER, ECONOMIC ANALYSIS, supra note 11, at 205-11. "Special" deterrence refers to the deterrence of the particular offender; "general" deterrence describes the deterrence of other potential offenders as well. FraNKLIN E. ZIMRING \& GORDON J. HAWKINS, DETERRENCE 72-74 (1973).

123. See, e.g., PACKER, supra note 14, at 356 (suggesting sole use of criminal sanction in area of economic offenses is deterrence); Developments, supra note 14, at 1235-36 ("Since corporate activity is normally undertaken in order to reap some economic benefit, corporate decisionmakers choose courses of action based on a calculation of potential costs and benefits. The calculating criminal is the one best deterred by punitive sanctions." (footnote omitted)).

124. See U.S.S.G., supra note 4, § 8D1.4(b)(2), (c)(4).

125. For provisions for the appointment and payment of experts, see U.S.S.G., supra note $4, \S 8 \mathrm{D} 1.4-$ (b)(2), (c)(4).

126. For guidelines providing for company-sponsored adverse publicity, see id. § 8D1.4(a). But see PACKER, supra note 14, at 361 (finding "very little evidence to suggest that the stigma of criminality means anything very substantial in the life of a corporation"); Comment, supra note 27, at 287-89 n.35 (questioning effectiveness of "moral opprobium" on corporate crime).

127. Parker, supra note 11 , at 571 . 
prevent misconduct, diverting money from value-maximizing transactions. ${ }^{128}$ In contrast, monetary conditions of probation such as fines and restitution are more easily predicted, and-if sufficiently high-can more precisely deter.

Similarly, where probation conditions weaken a company's financial status, shareholders may have trouble ascertaining whether existing management's, the court's, the probation officer's, or a court-appointed expert's decisions are responsible. These same problems do not characterize the effects of fines and restitution on the value of a company's stock. Shareholders can easily perceive the connection between a hefty fine and falling share value and exercise their prerogatives-to sell or to hold the stock or to vote against management-in a more rational manner.

\section{Incapacitation}

The SRA's third purpose is to protect the public from further wrongdoing by the particular offender. ${ }^{129}$ This punishment objective focuses heavily on recidivists; it purports to identify the particular offenders most likely to commit additional offenses and to prevent them from doing so. ${ }^{130}$ Some commentators do not consider incapacitation, which usually means incarceration for individual defendants, applicable to corporate criminals. ${ }^{131}$ Yet to the extent that incapacitation simply involves preventive, restraining measures, corporate behavior is restricted. ${ }^{132}$

Probation under the new guidelines includes some of the most incapacitating corporate sanctions available. A particularly restrictive form of probation requires a monitoring officer to review and investigate the company's compliance programs ${ }^{133}$ and puts the company's decisionmaking under close supervision of the court or its officers. ${ }^{134}$ Indeed, other than incapacitation through

128. Id. at 573 ("Spending more than the optimal amount of resources on control increases the amount of harm from organizational crime by making control more harmful than the crime itself.").

129. See 18 U.S.C. $\$ 3553(a)(2)(C)$ (1988).

130. See, e.g., S. REP. No. 225 , supra note 42 , at 76 , reprinted in 1984 U.S.C.C.A.N. at 3259; voN HIRSCH, supra note 111, at 19 (describing this function of punishment as "predictive restraint").

131. See, e.g., PACKER, supra note 14, at 356; Developments, supra note 14, at 1235.

132. Consider, for example, Judge Doumar's discussion of corporate "imprisonment" in the Allegheny Bottling case. See United States v. Allegheny Bottling Co., 695 F. Supp. 856, 859-61 (E.D. Va. 1988), aff'd in part \& rev'd in part sub nom. United States v. Harford, 1988-2 Trade Cas. (CCH) I 68,386 (4th Cir.), cert. denied, 493 U.S. 817 (1989); supra text accompanying notes 56-63; see also Donald R. Richberg, The Imprisonment of Criminal Corporations, 18 CASE \& COM. 527 (1912) (suggesting form of receivership as corporate imprisonment).

Senate bills authorizing incapacitating measures such as the suspension or restriction of a convicted company's participation in interstate commerce have failed. See S. REP. No. 225, supra note 42, at 68-69, reprinted in 1984 U.S.C.C.A.N. at $3251-52$ (discussing rejection of S. 1, 93d Cong., 1st Sess. \$ 1-4A1(c)(1) (1973) (authorizing suspension of organization's right to participate in interstate or foreign commerce), and S. 1437, 95th Cong., Ist Sess. \$ 2103(b)(6) (1977) (authorizing condition of probation restraining participation in specified business "bearing a reasonable relationship to the offense"), because too likely to unduly burden otherwise legitimate business).

133. See U.S.S.G., supra note $4, \S 8 \mathrm{Dl} 1.4(\mathrm{~b})(2)$, (c)(3).

134. Id. $\$ 8 \mathrm{D} 1.4(\mathrm{~b})(3),(\mathrm{c})(4)$. 
the corporate "death penalty," haps the most incapacitating sanction in the new guidelines. While probation for individuals offers "a conditional loss of liberty,"136 supervised structural reform of companies through probation involves an actual loss of liberty, not a conditional one. In this way, corporate probation conditions imposing structural controls ${ }^{137}$ closely parallel incarceration, not probation, for individual criminals. In contrast, "supportive" corporate probation does involve only a "conditional loss of liberty": if the company fails to comply with the monetary or remedial conditions, it will lose its liberty, and the less intrusive sort of probation will be revoked and replaced with the more invasive variety. ${ }^{138}$ Consistency with incapacitation principles suggests that recidivist companies and companies that violate terms of probation should be the targets of the more burdensome probation. The new guidelines, however, conflate intrusive and supportive corporate probation by failing to distinguish the circumstances in which each sort is appropriate.

\section{Rehabilitation}

Although the SRA lists rehabilitation as a sentencing objective, it deemphasizes this goal by rejecting the "outmoded rehabilitation model," which had served as the primary justification for previous sentencing schemes, including the Federal Probation Act. ${ }^{139}$ Moreover, the SRA's language of rehabilitation seems plainly inapplicable to organizations; it cites an aim "to provide the defendant with needed educational or vocational training, medical care, or other correctional treatment." ${ }^{, 140}$ Underlying the rehabilitative ideal is the notion that the criminal law can reform defendants to make them law-abiding. ${ }^{141}$ At one level, rehabilitation of corporate offenders seeks to reform the responsible individuals within the organizations. For that purpose, the use of corporate probation-or of corporate sanctions at all, for that matter-seems misguided. Yet proponents of the Structural Reform Model envision a different sort of

135. The guidelines provide for maximum fines sufficient to divest a company of all of its net assets. See id. $\S 8 \mathrm{C1}$.1; see also Guidelines Adopted, supra note 70, at 2661 (describing $\S 8 \mathrm{C1} .1$ as "the organizational equivalent of the death penalty").

136. PACKER, supra note 14 , at 275.

137. See Leonard Orland, Corporate Punishment By the U.S. Sentencing Commission, 4 FED. SENTENCING REP. 50, 50 (1991); $c f$. Letter from Jon V. Heider \& Thomas B. Leary, The Business Roundtable, to Judge William W. Wilkins, Jr., chairman of the U.S. Sentencing Commission, and members of the Commission 8 (Sept. 27, 1990) (on file with author) (characterizing corporate probation as "an extraordinary remedy which should be imposed only to meet a specific need").

138. If the company fails to comply with these conditions, the court may modify the terms of probation to make them more intrusive. See U.S.S.G., supra note $4, \S 8 D 1.5$.

139. See S. REP. NO. 225, supra note 42, at 38, reprinted in 1984 U.S.C.C.A.N. at 3221; Harvey M. Silets \& Susan W. Brenner, The Demise of Rehabilitation: Sentencing Reform and the Sanctioning of Organizational Criminality, 13 AM. J. CRIM. L. 329, 371 (1986).

140. 18 U.S.C. $\$ 3553$ (a)(2)(D) (1988); see also Silets \& Brenner, supra note 139, at 363 ("Obviously, the fourth factor $[\S 3553(a)(2)(D)]$ is inapplicable to the corporate defendant.").

141. See, e.g., VON HIRSCH, supra note 111 , at 11 n.*. 
corporate rehabilitation: the reform of companies' internal control and communication systems, ensuring that subordinate employees follow the plans of upper management and that information about subordinate employees' conduct is transmitted back to management. ${ }^{142}$

In most circumstances, probation under the new guidelines will promote such corporate rehabilitation less efficiently than fines will. It seems hard to quarrel with the notion that companies with inadequate internal control and communication systems should reform them. But those most familiar with the quirks of a company's structure, long-range goals, customers, creditors, and financial status are usually in the best position to see how to reform the firm's incentive, communication, and compliance mechanisms. Surely the organization itself is usually best equipped to make such rehabilitative changes cost-effectively. ${ }^{143}$ Fines under the new guidelines provide incentives for such reform in the form of mitigating factors for compliance efforts. ${ }^{144}$ Moreover, a 1991 study suggests that most companies react to monetary penalties by instituting reforms; the others go out of business. ${ }^{145}$ In extraordinary circumstances, however, significant structural defects may hinder a company's ability to respond to the incentives and disincentives created by the new fines under the guidelines. A recidivist company will have failed to implement reforms fully in response to monetary sanctions. In that scenario, closely supervised rehabilitation seems warranted. The guidelines do not limit structural probation to such instances; they should. Society can usually best achieve the often-legitimate end of corporate rehabilitation without judicial oversight by using monetary sanctions and monetary conditions of probation, rather than court intervention in corporate governance.

\section{Determinacy}

Determinate sentencing "underline[s] the major premise of the sentencing

142. See, e.g., James A. Geraghty, Note, Structural Crime and Institutional Rehabilitation: A New Approach to Corporate Sentencing, 89 YALE L.J. 353 (1979).

143. See POSNER, ECONOMIC ANALYSIS, supra note 11, at 397-98; Parker, supra note 11, at 573; cf. Gruner, supra note 18, at 80-85 (recognizing efficiency advantages of corporate monitoring as opposed to governmental monitoring).

144. See U.S.S.G., supra note $4, \S 8 \mathrm{C} 2.5(\mathrm{f})$; Arkin, supra note 76, at 4 (arguing that fines under guidelines will increase compliance efforts, for such efforts "could result in a modest fine rather than a nuinous one.").

145. See Section of Criminal Justice, aba, Final Report: Collateral Consequences of CONVICTIONS OF ORGANZATIONS 80-82, 107-08 (1991). Based on federal prosecutions of the last two years, the ABA study found that $75 \%$ of the convicted corporations surveyed were still in operation. Id. at 107 . Of those, in response to their convictions, $59 \%$ had initiated or expanded a prevention program, $57 \%$ had implemented or expanded a surveillance program, $41 \%$ had replaced senior management, $29 \%$ had replaced middle management, $26 \%$ had implemented a new accounting system, $16 \%$ had initiated or expanded a peerreview process, and $10 \%$ had fired everyone responsible. Id. at 108 . Which sanctions prompted these companies to react in these ways? Fines were imposed in $91 \%$ of the cases. Id. at $80 ; c f$. Feder, supra note 28, at F5 ("Companies are fighting the high cost of misconduct with ethics programs." (emphasis added)). 
guidelines-the need to avoid unwarranted sentencing disparity."146 Congress enacted the SRA largely in response to complaints about the unfettered sentencing discretion of federal district judges and parole officers. ${ }^{147}$ Consistency and predictability are desirable features of a sentencing scheme on both consequentialist and retributive grounds: these features foster a more accurate cost/benefit analysis by the potential criminal, enhancing deterrence; they also fit with notions of "fairness" by treating similarly culpable defendants similarly.

The provisions for corporate probation under the new guidelines undermine the SRA's commitment to determinacy by leaving considerable room for variation among probationary conditions, while purporting to curb judicial discretion. By following the "if $X$, then $Y$ " format of the guidelines, a judge imposes sentences that seem mechanical and predetermined. Yet the new guidelines give judges insufficient guidance in assessing both when to put a corporation on probation and what conditions to impose.

Three triggers of probation under the new guidelines encompass enough situations to swallow the usefulness of probation guidelines: (1) the need "to accomplish one or more of the purposes of sentencing"; 148 (2) the need "to ensure that changes are made within the organization to reduce the likelihood of future criminal conduct"; 149 and (3) the occurrence of "similar misconduct" by the company or a high-level official within the last five years. ${ }^{150}$ These triggers rely heavily on the judge's interpretation of ambiguous language and transfer significant power to the prosecutor. First, the judge receives little guidance from the question-begging provision that authorizes probation whenever "necessary to accomplish one or more of the purposes of sentencing."151 Second, the judge's assessment of the adequacy of a company's compliance efforts or the likelihood of future misconduct will depend largely on the prosecutor's characterization of the same. Hence, plea and charge bargaining outside of the judge's presence will increase, as prosecutors wield considerable leverage because of their ability to influence the judge's decision whether to subject a company to invasive supervision. ${ }^{152}$ In this way, what discretion the guidelines take away from the judge they award to the prosecutor. ${ }^{153}$ And

146. S. REP. No. 225, supra note 42, at 78, reprinted in 1984 U.S.C.C.A.N. at 3261.

147. Id. at 49-50, reprinted in 1984 U.S.C.C.A.N. at 3232-33.

148. U.S.S.G., supra note $4, \S 8 D 1.1(a)(8)$.

149. Id. \& 8D1.1(a)(6).

150. Id. \& 8D1.1(a)(4)-(5).

151. Id. \& 8D1.1(a)(8).

152. Cf. Hearings on the Sentencing Guidelines Before the Subcomm. on Criminal Justice of the House Comm. on the Judiciary, 100th Cong., 1st Sess. 816-36 (1987) (statement of Prof. Albert Alschuler) (discussing prosecutor's plea and charge bargaining leverage stemming from guidelines' incarceration provisions for individuals).

153. Cf. Stephen J. Schulhofer \& Ilene H. Nagel, Negotiated Pleas Under the Federal Sentencing Guidelines: The First Fifteen Months, 27 AM. CRIM. L. REV. 231, 256-88 (1989) (discussing ways in which prosecutorial discretion, through plea, guideline-factor, and charge bargaining, can undermine sentencing guidelines); Peter B. Pope, Note, How Unreliable Factfinding Can Undermine Sentencing Guidelines, 95 YALE L.J. 1258 (1986) (arguing that guidelines conceal factfinding problems). See generally ABRAHAM S. 
where the SRA requires the judge to consider determinacy, the Department of Justice Manual imposes no such restriction. ${ }^{154}$ Third, where the guidelines do provide more specific guidance, they point to factors that may implicate almost every sizable corporate defendant. Under the guidelines' idea of "similar misconduct," for instance, all sorts of fraud (e.g., medicare, securities, consumer) are considered "similar,"155 even though compliance programs targeting the different types of fraud must address different divisions, different employees, different scenarios, and different victims. In sum, the guidelines provide little meaningful differentiation between appropriate and inappropriate occasions for corporate probation.

Similarly, once a judge deems corporate probation appropriate under the guidelines, he has little help in designing the conditions. For example, a judge making adverse publicity a condition of probation ${ }^{156}$ has no guidance on the media to specify, the amount the company must spend, the size of the campaign, or the degree to which the company may include other messages in the advertisements. The "loose cannon" problems identified by commentators seem alive and well in this part of the guidelines. ${ }^{157}$

\section{Restitution}

The SRA includes restitution as a sentencing goal. ${ }^{158}$ This goal, traditionally one of civil law, ${ }^{159}$ had previously been available only as a condition of probation. ${ }^{160}$ Restitution is now an independent sentence, ${ }^{161}$ although it may also function as a condition of probation under the guidelines. ${ }^{162}$ By adding the threat of probation revocation, a sentencing court can increase the consequences that a company faces for failing to make ordered restitution. Structural

Goldstenn, THe Passive Judictary: PRosecutorial Discretion and the GuLty Plea (1981).

154. Department of Justice policy calls for prosecutors to consider several factors; determinate sentencing is not one of them. See 8 U.S. DEP'T OF JUSTICE, THE DEPARTMENT OF JUSTICE MANUAL $\$ 740$ \& cmt., at 9-545 to 9-547 (Supp. 1990-2) (listing considerations for sentencing recommendations). A prosecutor may make sentencing recommendations, including "innovative conditions of probation," whenever "[t]he public interest warrants an expression of the government's view concerning the appropriate sentence."

Id. $\$ 730$ \& cmt., at 9-543 to $9-545$.

155. U.S.S.G., supra note 4 , § 8 A1.2 cmt. 3(f).

156. Id. \& 8D1.4(a).

157. See, e.8., Coffee, supra note 18, at 424-34 (discussing problems of adverse publicity sanctions).

158. 18 U.S.C. \& 3553(a)(7) (1988).

159. See Abraham S. Goldstein, Defining the Role of the Victim in the Criminal Prosecution, 52 MISs. L.J. 515, 521 (1982) (noting "restitution [in the criminal process] came into vogue in the United States . . in the late nineteenth and early twentieth centuries as part of the increasing emphasis on rehabilitation"). The difficulty of distinguishing between such criminal sanctions and civil ones is beyond the scope of this Note and is discussed at length elsewhere. See generally Kenneth Mann, Punitive Civil Sanctions: The Middleground Between Criminal and Civil Law, 101 YALE L.J. 1795 (1992) (describing restitution as paridigmatic purpose of civil law, yet noting collapsing distinction between civil and criminal paradigms).

160. See United States v. RICO Indus., 854 F.2d 710 (5th Cir. 1988) (corporation cannot be ordered to pay restitution unless sentenced to probation), cert. denied, 489 U.S. 1078 (1989).

161. See 18 U.S.C. $\$ \$ 3663-3664$ (1988).

162. See U.S.S.G., supra note $4, \S \S 8 \mathrm{~B} 1.1,8 \mathrm{D} 1.1(\mathrm{a})(1)$. 
reform through probationary monitoring need play little role if restitution is the primary purpose and if the corporate defendant can pay. Probation can be useful, however, as a threat with which to ensure compliance by a corporation sentenced to pay restitution as its main condition of probation.

\section{B. Juxtaposition with Administrative and Civil Enforcement Mechanisms}

The discussion thus far has focused on the problems and dangers of the new corporate probation guidelines. A comparison of these provisions with available administrative and civil enforcement mechanisms raises an additional question: What can corporate probation accomplish that cannot already be achieved through these other channels? A wide array of nonmonetary corrective sanctions function much like probation of the structural reform variety. The Department of Defense may debar or suspend contractors; ${ }^{163}$ the FDIC may issue cease-and-desist orders, suspend an institution's insurance, or place it in conservatorship or receivership; ${ }^{164}$ the SEC has broad injunctive and ceaseand-desist powers, and the authority to suspend companies from the securities industry; ${ }^{165}$ the Department of Health and Human Services may exclude health care providers from medicare and medicaid programs; ${ }^{166}$ the EPA has broad injunctive and debarment authority; ${ }^{167}$ the FDA may obtain injunctions or seize adulterated or misbranded products, ${ }^{168}$ the FTC may obtain injunctions, cease-and-desist orders, and orders correcting false advertising; ${ }^{169}$ and so on. ${ }^{170}$

163. See Federal Acquisition Regulations, 48 C.F.R. $\$ \S 9.403,9.406-4(a), 9.407-4$ (a)-(b) (1990). The presence of "reasonable procedures designed to prevent and detect violations" may help a contractor avoid debarment. Id. \$\$ 3.502-2(i)(1), 9.406-1(a).

164. See Financial Institutions Reform, Recovery, and Enforcement Act of 1989 (FIRREA), 12 U.S.C. $\S \S 1786,1818$ (1988 \& Supp. I 1989).

165. See Securities Act of 1933, 15 U.S.C. $\$ 77 t(b)$ (1988); Securities Exchange Act of 1934, 15 U.S.C.A. $\S \S 780(b)(4)-(6), 78 u(d)-(e)$ (West 1981 \& Supp. 1991); Investment Advisers Act of 1940, 15 U.S.C.A. \& 80b-3(e)-(k) (West 1981 \& Supp. 1991); SEC v. ITT, [1979 Transfer Binder] Fed. Sec. L. Rep. (CCH) 96,948, at 95,959-63 (D.D.C. Aug. 8, 1979) (corporation agreed to take specified steps to prevent future securities violations).

166. See Medicare and Medicaid Patients and Program Protection Act of 1987, 42 U.S.C.A. $\$ 1320 \mathrm{a}-7$ (1988 \& Supp. I 1989); 42 C.F.R. \$\$ 1001.1 to 1004.130 (1991).

167. See Federal Insecticide, Fungicide and Rodenticide Act (FIFRA), 7 U.S.C. $\$ 136 d$ (1988); Toxic Substances Control Act (TSCA), 15 U.S.C. $\$ \$ 2606,2616$ (1988); Federal Water Pollution Control Act (Clean Water Act), 33 U.S.C. $\S \S 1319$ (a), 1415 (1988); Safe Drinking Water Act, 42 U.S.C. § 300j(e) (1988); Noise Control Act of 1972, 42 U.S.C. $\$ 4910$ (1988); Resource Conservation and Recovery Act of 1976 (RCRA), 42 U.S.C. $\S \S 6928(a)(1), 6973$ (1988); Clean Air Act, 42 U.S.C. $\$ 7414$ (1988); Comprehensive Environmental Response, Compensation, and Liability Act (CERCLA), 42 U.S.C. $\$ 9606$ (1988).

168. See Federal Food, Drug, and Cosmetic Act, 21 U.S.C. $\$ \S 332,334$ (1988).

169. See Federal Trade Commission Act, 15 U.S.C. $\$ 45(b),(l)$ (1988); see also Wamer-Lambert Co. v. FTC, 562 F.2d 749, 763-64 (D.C. Cir. 1977) (upholding corrective advertising order against First Amendment challenge), cert. denied, 435 U.S. 950 (1978).

170. The agencies listed have authority to punish about $70 \%$ of corporate crimes: procurement and program fraud, banking crimes, securities fraud, medicare and medicaid fraud, environmental offenses, food and drug violations, antitrust offenses, and consumer fraud. See, e.g., Mark A. Cohen, Empirical Trends in Corporate Crime and Punishment, 3 FED. SENTENCRG REP. 121 (1990); Parker, supra note 11, at 530-31 
The existence of such mechanisms in the absence of the corporate probation guidelines has conflicting implications. On the one hand, probation seems less problematic if such interventionist devices are already acceptable in the legal system. On the other hand, probation seems redundant if these other weapons are available. The redundancy argument prevails because the administrative and civil processes hold two distinct advantages over probation. First, a court or probation officer monitoring a company's compliance with a particular regulatory regime has neither the resources nor the expertise of the administrative agency charged with enforcing the laws in question. ${ }^{171}$ The FDA, for instance, will be far better at gauging a company's program for preventing and detecting food and drug violations than a court will. Indeed, relying on the agency for such oversight is consistent with its mandate; relying on the court to do the same adds significantly to its already overflowing docket. ${ }^{172}$ Nor will delegating the monitoring to a court-appointed expert solve this problem. Although the company on probation would pay the expert's expenses and fee, ${ }^{173}$ this is hardly an efficient allocation of resources: it is more cost effective for the company to implement or expand its own program or to have an agency already monitoring the industry increase its scrutiny. The court, moreover, will still have to spend time reviewing the expert's findings and recommendations and settling disputes between the company and the expert. Second, the agency has a more precisely defined jurisdiction. EPA officials may supervise a company's environmental controls, but not its marketing procedures or compliance with the federal securities laws. In contrast, a judge or probation officer receives much less guidance as to which corporate operations fall within his oversight authority.

\section{LIMITINg CoRporate PROBation: AMENDing the GUidelines}

The guidelines' corporate probation provisions need revision. The Commission should amend the guidelines to stress the extraordinary nature of this sanction and the limited circumstances in which its application is justified. Such restrictions would not eliminate the use of corporate probation; they would, however, rescind the new guidelines' invitation to district courts to misapply

tbl. 3. This list is not exhaustive and does not include private actions seeking injunctive relief, state processes, or civil enforcement by the Department of Justice.

171. See, e.g., Einer Elhauge, Does Interest Group Theory Justify More Intrusive Judicial Review?, 101 YALE L.J. 31, 80 (1991). Even Coffee acknowledges the inadequacy of the U.S. Probation Service to gather facts on corporate criminals. See John C. Coffee Jr., Let's Not Shield Corporations From Criminal Penalties, Legal TIMEs, Feb. 13, 1989, at 19, 21.

172. The fear of agency "capture" by the industry it regulates might justify reliance on the more insulated judicial branch for the monitoring of corporate offenders. Yet the actual risk of capture is in question, see, e.g., JAMES Q. WILSON, BUREAUCRACY: WHAT GOVERNMENT AGENCIES DO AND WHY THEY Do Ir 72-89 (1989), and the insulation of the judiciary has been challenged as well, see, e.g., Elhauge, supra note 171, at 81-83 (interest groups may unduly influence judicial appointments).

173. See U.S.S.G., supra note $4, \& 8 D 1.4(\mathrm{~b})(2)$, (c)(4). 
the sanction. There are four major elements to this revision.

First, the Commission should modify chapter eight's introductory commentary, which sets forth "general principles" for the sentencing of organizations. Part of this section invites courts to apply probation too often-whenever needed "to ensure that steps will be taken within the organization to reduce the likelihood of future criminal conduct."174 Instead, the Commission should instruct courts that "probation may be appropriate for an organizational defendant when needed to ensure that another sanction will be fully implemented or when the organization has exhibited significant recidivism or disregard for monetary sanctions." This would limit the use of corporate probation to enforcing other sanctions, such as fines and restitution, and to addressing those situations in which collectibility or marked recidivism is a problem.

Second, the Commission should amend section 8D1.1, which lists eight circumstances requiring the imposition of probation. This amendment would both reduce the number of situations justifying the use of probation and add a provision focusing on recidivists. The current list encompasses so many situations that it invites probation whenever the court-heavily influenced by the prosecutor-disapproves of a company's compliance program, ${ }^{175}$ decides future misconduct is likely, ${ }^{176}$ or feels probation is appropriate "to accomplish one or more of the purposes of sentencing." 177 The Commission should leave only two triggers, requiring probation (1) "if such sentence is necessary to secure payment of restitution, enforce a remedial order, or ensure completion of community service;",178 and (2) if "restrictions are necessary to safeguard an organization's ability to make payments." 179 These triggers permit courts to use probation as additional leverage to ensure compliance with monetary sanctions and remedial orders and to ensure the collection of fines. Because this section should address recidivism more directly, the Commission should add a new section:

\section{§ 8D1.6. Limitation on Imposition of Probation-Organizations}

(a) The court shall not order a term of probation for any reason other than those listed in $\S 8 \mathrm{D} 1.1$ (a), unless it determines that a departure from the guidelines is warranted under $\S 8 \mathrm{D} 1.6(\mathrm{~b})$.

(b) Departure from $\S 8 \mathrm{D} 1.6(\mathrm{a})$ 's limitation on the imposition of probation may be warranted:

(1) if the organization has violated a condition of probation imposed either for the instant offense or for a

174. Id. ch. 8 , intro. cmt.

175. Id. $\S 8 \mathrm{D} 1.1(\mathrm{a})(3)$.

176. $I d . \S 8 \mathrm{D} 1.1(\mathrm{a})(6)$.

177. Id. \& $8 \mathrm{D} 1.1(\mathrm{a})(8)$.

178. Id. $\$ 8 \mathrm{D} 1.1(\mathrm{a})(1)$ (references omitted).

179. Id. $\$ 8 \mathrm{D} 1.1(\mathrm{a})(2)$. 

previous one; or
(2) if within the last five years, the organization has been convicted of violating the same statute that it has violated in the instant offense.

By stressing recidivism, this new section focuses the application of probation on corporate offenders of the worst kind: those corporations that ignore the lessons inflicted by monetary sanctions. At the same time, however, this section defines recidivism narrowly to emphasize the exceptional nature of this kind of corporate criminal. To justify probation on grounds of recidivism, a judge would have to find circumstances so exceptional as to warrant departure from the guidelines. ${ }^{180}$ By making such a determination, the judge communicates to both the convicted company and the public that the case warranted the extreme measure of probation because it fell outside the "heartland" of typical cases. $^{181}$

Third, the Commission should amend section 8D1.4, which lists various conditions of probation. The changes here would more narrowly tailor conditions of probation to the circumstances justifying probation in the first place. To limit the use of the stigma sanction to recidivists, subsection (a), which provides for adverse publicity orders, should now begin with the limiting phrase: "If probation is imposed under $\S 8 D 1.6(b)$." Subsection (b) provides for probation where "necessary to safeguard the organization's ability to pay any deferred portion of an order of restitution, fine, or assessment." This subsection should remain intact, for it simply suggests conditions for situations in which collectibility is seriously in question. Subsection (c), which lists conditions for court monitoring of a company's compliance program, should now apply only "if probation is imposed under $\S 8 \mathrm{D} 1.6(\mathrm{~b})$," that is, only where recidivism triggered the probation.

Finally, the Commission should amend the application note that accompanies section 8D1.4. An addition to this note would emphasize and clarify the need for a reasonable relationship between the probationary supervision and the nature of the offense. It should add a new paragraph: "When ordering an organization to expand or implement a program to prevent and detect violations of law, the court should restrict its order to those units and operations of the organization that participated in the misconduct underlying the instant offense." This addition would sternly remind courts and probation officers to try to "fix" only the "broken" parts of corporate probationers.

180. Under 18 U.S.C. 3553(b) (1988), departure may be warranted if the court finds "that there exists an aggravating or mitigating circumstance of a kind, or to a degree, not adequately taken into consideration by the Sentencing Commission in formulating the guidelines that should result in a sentence different from that described." Such departure mechanisms already exist as bases for other sanctions in the guidelines. See U.S.S.G., supra note 4, $\$ 5 \mathrm{~K} 2$ (grounds for departure from prison terms for individuals); id. $\$ \S 8 \mathrm{C} 4.2-.11$ (grounds for departure from fines for organizations).

181. See U.S.S.G., supra note 4, ch.1, pt. A, intro. 4(b) (describing departure rationale). 


\section{CONCLUSION}

This Note has examined the guidelines' corporate probation provisions on several fronts. Assessing the provisions against the SRA's purposes shows that probation is less accurately retributive than monetary sanctions, unpredictable in its deterrent and rehabilitative effects, approaching corporate imprisonment in its incapacitating potential, and undermined by prosecutorial discretion and ambiguous language. When juxtaposed with available administrative and civil sanctions, corporate probation seems redundant and inefficient.

In light of these flaws, the Commission should amend the guidelines to place a heavier emphasis on purely monetary sanctions: fines and restitution. When imposed, probation conditions should be limited to those which guarantee that the offender will comply with underlying monetary sanctions. Monitoring through probation should apply only to judgment-proof and recidivist corporations. Finally, the Commission should restrict supervision and second-guessing by courts and probation officers to only those corporate units and activities involved in the offense of conviction. By limiting corporate probation in this manner, the Commission will promote the purposes of punishment and avoid imposing a judicially managed regulatory regime. 